\author{
Per-Einar Scebbe \\ Universitetet i Stavanger
}

DOI: http://dx.doi.org/10.5617/adno.4022

\title{
«Her var det to sauer» \\ Om barnehagelæreres matematikkfokuserte kompetanse
}

\section{Sammendrag}

Barnehagelærernes kompetanse blir ofte trukket fram som barnehagens viktigste ressurs, men likevel har norsk barnehageforskning i liten grad undersøkt hva barnehagelcererne i barnehagen gjør og hvilken kompetanse de bruker når de jobber med matematikk. Det blir ofte tatt for gitt at det er sammenheng mellom lcererens kompetanse og barnas lcering, men få studier har undersøkt hvorfor og hvordan disse sammenhengene viser seg i praksis. Forskningen har i all hovedsak konsentrert seg om hvilken kompetanse larerne har eller trenger - uten å undersøke empirisk hvilken kompetanse de bruker i sin profesjonelle praksis. Den økende satsingen på realfag i barnehagen aktualiserer behovet for forskning som kan bidra til å utvikle ny kunnskap om hvordan matematikkarbeid i barnehagen gjennomføres og hvilke kompetansekrav dette stiller til barnehagelcererne. Slik forskningsbasert kunnskap kan bidra til mer bevisst arbeid med matematikk i barnehagen, og til å utvikle innholdet i matematikkundervisningen i barnehagelcrerutdanningen til bedre å møte de kravene norsk barnehage stiller til barnehagelcerernes kompetanse. Resultatene fra en kvalitativ casestudie av fem barnehagelcerere indikerer og bekrefter at barnehagelcerernes kompetanse i matematikk består av fagkompetanse og didaktisk kompetanse. I tillegg ser det ut til at barnehagelcerernes kompetanse til å skape felles oppmerksomhet er essensiell for arbeidet med matematikk $i$ barnehagen. I den nordiske barnehagetradisjonen, der arbeidet preges av lek og hverdagsaktiviteter, skal det i alle barnehager arbeides målrettet med matematikk. Rammeplan for barnehagens innhold og oppgaver gir barnehagelæererne ansvaret for dette arbeidet og kaller fagområdet for Antall, rom og form.

Nøkkelord: barnehagelcerere, matematisk kompetanse, matematikkundervisning 


\title{
"There are two sheep here" \\ On kindergarten teachers' mathematical competence
}

\begin{abstract}
Kindergarten teachers' competence is often considered to be the most important asset of kindergarten, but Norwegian early childhood education researchers have still paid little attention to investigating what kindergarten teachers are doing and what competence they use when working with mathematics in kindergarten. It is often taken for granted that there is a connection between teachers' competence and children's learning, but few studies attempt to understand why and how these connections appear in practice. Research has primarily concentrated on what competence teachers have or need - without empirically examining what competence they use in their professional practice. The increasing focus on mathematics and science in kindergarten highlights the need for research that might contribute to generating new knowledge about how mathematical work is implemented in kindergarten and what competence demands this poses for the kindergarten teachers. This kind of research based knowledge might lead to more intentional mathematical work in kindergarten, and to development of the content of mathematics teaching in kindergarten teacher education in order to better face the demands that Norwegian kindergarten poses in terms of kindergarten teachers' competence. The results from a qualitative case study of five kindergarten teachers indicate that kindergarten teachers' competence in mathematics consists of content knowledge as well as didactical competence in mathematics. In addition, it appears that kindergarten teachers' competence in reaching joint attention is essential to the work of teaching mathematics in kindergarten. In the Nordic kindergarten tradition, where the main focus is on play and everyday activities, every kindergarten is still required to carry out intentional mathematical work. The national framework for kindergarten places the responsibility for this work with the kindergarten teachers - in the framework, this learning area is called Quantities, spaces and shapes.
\end{abstract}

Keywords: kindergarten teachers, mathematical competence, mathematics teaching

\section{Innledning}

Fra sentralt hold blir barnehagepersonalets kompetanse løftet fram som «den viktigste enkeltfaktoren for at barn skal trives og utvikle seg i barnehagen» (Kunnskapsdepartementet, 2013, s. 57), og man kan anta at det er en sammenheng mellom barnehagelærerens kompetanse i matematikk og barnas læring av 
matematikk i barnehagen. Likevel er det få studier som har undersøkt hvordan barnehagelæreres (eller lærere i skolen) kompetanse påvirker barns læring av matematikk (Hoover, Mosvold, Ball \& Lai, 2016; Mosvold, 2017). Mye av den tradisjonelle forskningen om matematikk i barnehagen dreier seg om barns matematiske utvikling og har blitt gjort innenfor en psykologisk tradisjon ved hjelp av kliniske intervjuer. Få studier har hatt fokus på matematikk i naturlige omgivelser i tilknytning til lek og hverdagsaktiviteter i barnehagen (Reikerås, Løge \& Knivsberg, 2012). Den nye Rammeplan for barnehagens innhold og oppgaver (Kunnskapsdepartementet, 2017) sier at arbeidet med fagområdene skal oppleves som en meningsfull del av barnehagens hverdag, og at planleggingen av arbeidet skal synliggjøre hvordan barnehagen fortolker og realiserer rammeplanen. I en nordisk kontekst har det, så vidt jeg kjenner til, foreløpig ikke vært noen studier av hvordan barnehagelærere bruker egen kompetanse i matematikk og hvordan de selv ser på egen kompetanse i sin profesjonelle praksis.

Begrepet undervisning blir vanligvis ikke brukt i den norske barnehagetradisjonen (Pramling Samuelsson, 2016), og jeg har i denne studien valgt å kalle matematikkundervisningen for arbeid med matematikk. Jeg legger til grunn at alt barnehagelæreren gjør i den hensikt å støtte barnas læring av matematikk, vil kunne kalles matematikkundervisning - inklusive planlegging og evaluering av slike aktiviteter (jf. Ball \& Forzani, 2009). Amerikanske forskere hevder at matematikkundervisning i skole og barnehage er likt (Ginsburg \& Amit, 2008), men Mosvold, Bjuland, Fauskanger og Jakobsen (2011) argumenterer for at det er forskjeller mellom amerikansk og norsk barnehagekontekst og etterlyser mer forskning som kan utdype disse forskjellene.

Den nordiske barnehagetradisjonen plasseres innenfor det OECD (2006) kaller en «sosialpedagogisk tradisjon», med et vidt og åpent læringssyn der barna lærer gjennom lek og hverdagsaktiviteter. Den amerikanske barnehagetradisjonen kalles for en skoleforberedende («pre-primary») tradisjon, og barnehagelærerne har mer fokus på skolelignende undervisning. Siden 19951996 har matematikk vært et obligatorisk fag i barnehagelærerutdanningen i Norge, og med revideringen av rammeplanen i 2006 ble matematikk (fagområdet Antall, rom og form) ett av kunnskapsområdene som alle barnehager er forpliktet til å arbeide med (Kunnskapsdepartementet, 2006). I Nasjonal strategi for realfag i barnehagen og grunnopplceringen 2015-2019 (Kunnskapsdepartementet, 2015) etterlyses det mer kunnskap om hvordan det realfaglige arbeidet foregår i praksis i norske barnehager. Forskning om barnehagelærernes kunnskaper i matematikk undersøker ofte hva barnehagelærerne trenger for å undervise i matematikk i barnehagen (Lee, 2010; McCray \& Chen, 2012). Studiene forsøker å utvikle redskaper som kan måle hvilken kunnskap barnehagelærerne trenger og undersøker dette gjennom å observere læringssituasjoner i barnehager i en amerikansk kontekst. I McCray og Chen (2012, s. 304) sine forsøk med å utvikle «Preschool Mathematics PCK Interview (PM- 
PCK)» for vise sammenhengen mellom effektiv undervisning i barnehagen og barnehagelærernes kunnskaper konkluderer de med:

\begin{abstract}
The work described here suggests that PCK for preschool mathematics requires an understanding of the foundational concepts of mathematical content, combined with the skill to closely observe children's play, discern their likely thinking, and provide language that points out embedded mathematics. Effective preschool teachers must recognize the importance and complexities of very basic experiences of size, shape, and quantity, and be prepared to label and connect such experiences for children.
\end{abstract}

Pedagogical Content Knowledge (PCK) defineres av Shulman (1986, s. 9) som «the ways of representing and formulating the subject that makes it comprehensible to students». Content Knowledge (CK) kan sies å være kunnskapen om faget og fagets struktur, både at det er slik og hvorfor det er slik (Shulman, 1986, s. 9). Forskere som McCray og Chen (2012) og Lee (2010) har fokus på å måle barnehagelærernes PCK, mens Björklund og Barendregt (2016) kombinerer den veletablerte teoretiske tradisjonen om PCK med utviklingspedagogikk i sin studie. Studier om hvordan barnehagelærerne bruker egen fagkompetanse og fagdidaktiske kompetanse i sitt profesjonelle arbeid med matematikk i barnehagen ser ut til å være nærmest fraværende. Da Shulman i 1986 snakket om «the missing paradigm» argumenterte han for å studere praksis for å forstå hvilken rolle faginnhold har i undervisning. Ball, Thames og Phelps (2008) kaller en slik tilnærming for «bottom up», fordi forskningen er praksisbasert, ikke basert på hvilke kunnskaper læreren trenger. Denne studiens mål er å imøtekomme behovet for forskning om barnehagelæreres kompetanse i matematikk og hvordan de bruker denne i hverdagsaktiviteter i barnehagen. I den norske barnehagetradisjonen der mye av det faglige arbeidet gjøres på en uformell måte, kan det være spesielt viktig å undersøke hvilken rolle faginnholdet har i undervisningsarbeidet for å utvikle en barnehagedidaktikk basert på aktivitetene som gjøres i barnehagen. Ball (2017) sier at «[...] what we need to be talking more clearly about is mathematical knowing and doing inside the mathematical work of teaching» (s. 14). Fokus endres fra hvilken kompetanse barnehagelærere trenger til hvilken kompetanse de bruker, samt til de mer uformelle hverdagsaktivitetene i norsk barnehagetradisjon - fordi arbeidet med matematikk skal prege barnehagens hverdag (Kunnskapsdepartementet, 2017). For å komme nærmere hverdagsaktivitetenes hvordan og hvorfor, har jeg gjort observasjoner og analyser av barnehagelærernes undervisningsarbeid i matematikk, og gjort intervjuer der de selv kommenterer egen praksis. Jeg søker gjennom studien å svare på følgende forskningsspørsmål:

Hvilken kompetanse bruker barnehagelærere til å støtte barnehagebarnas læring av matematikk gjennom hverdagsaktiviteter i barnehagen, og hvordan beskriver de egen kompetanse i sitt profesjonelle arbeid med matematikk? 


\section{Krav til barnehagelærernes kompetanse}

Doverborg, Pramling og Pramling Samuelsson (2013) hevder at de sosiokulturelle perspektivene i den nordiske barnehagetradisjonen også innebærer et fokus på hvordan barnehagelæreren tilrettelegger for barns læring, og skriver at barnehagelærerens ansvar er å samordne perspektivene og bruke et ekspansivt språk som gir barna redskaper til å gjenfortelle. Når Lee (2010) målte barnehagelærernes kompetanse innenfor seks områder, fant hun at de var best på tallforståelse (number sense) og arbeid med mønstre (pattern). Områdene sammenligning (comparison) og romforståelse (spatial sense) skåret de dårlig på. Lee (2010) sier at lærerne i barnehagen trenger å vite hvordan de skal utvikle barnas matematiske kompetanse på en forståelig måte, og etterlyser mer forskning som kan undersøke barnehagelærernes undervisningspraksis i barnehagen. McCray og Chen (2012) sier også at lærerne i barnehagen trenger forståelse for grunnleggende matematikk og for hvordan de kan tilrettelegge for barns læring av dette, mens Carlsen, Erfjord og Hundeland (2010) sier at barnehagelærernes ulike måter å stille spørsmål på har betydning for barns læring av matematikk. Björklund og Barendregt (2016) har i sin studie undersøkt tilstedeværende praksis og barnehagelærernes bevissthet i forhold til hvordan de bruker det fysiske miljøet til å tilrettelegge for matematikkaktiviteter. De finner at barnehagelærerne planlegger det matematiske innholdet, men de jobber i stor grad ut fra barnas egne initiativ i her-og-nå-situasjonene. Studien viser at lærerne mangler kompetanse i å utnytte mulighetene, for eksempel i det fysiske miljøet eller i tilgjengelig materiale til å jobbe med matematikk. Lærerne vet ikke nok om hvordan de skal fremstille matematikken, verken visuelt eller verbalt. Björklund (2013) hevder at barnehagelærerne også trenger kompetanse om innholdsdimensjonene i styringsdokumentene, samt at de må kunne tenke seg til hva barna kan lære i forhold til tematikken barnehagen jobber med. Siraj-Blatchford (2009) hevder at rammeplanmakernes «gode meninger» ofte er feil; planene er for opptatt av ferdigheter, kunnskaper og forståelser og har lite fokus på barnas egen kompetanse. Hun er opptatt av barnas egne initiativ og kreative kompetanse - noe hun kaller lcere å lcere - og at barnehagelærere trenger god kompetanse i å lære barna dette. Hundeland (2010) sier at matematikklærernes kompetanse utvikler seg i samspill med utfordringene de møter i praksis. Man kan dermed sannsynligvis ikke kun fokusere på den formelle utdanningen når en vurderer barnehagelæreres profesjonelle kompetanse i matematikk; den formelle utdanningen danner bare inngangsporten. En bevisstgjøring av barnehagelærerne er nødvendig - ikke for å gjøre dem til matematikere, men for å øke forståelsen for hva det vil si for barna å lære matematikk i barnehagen og hvilken rolle lærerne spiller i denne utviklingen (Björklund \& Barendregt, 2016).

Ball, Thames og Phelps (2008) har undersøkt hvilke kunnskaper lærere trenger og hvilke matematiske utfordringer de står overfor, og de har utviklet et teoretisk rammeverk om undervisningskunnskap i matematikk (på engelsk: 
Mathematical Knowledge for Teaching). Selv om teoriene er fra en amerikansk skoletradisjon, ser det likevel ut til at de kan være anvendbare i en norsk barnehagekontekst (Mosvold et al., 2011). Forskningen til Ball og hennes kollegaer har bakgrunn i studiene til Shulman (1986), som allerede for 30 år siden argumenterte for at lærere i tillegg til formell matematisk kunnskap også trenger fagdidaktisk kunnskap for effektivt å kunne undervise i matematikk. Ball mfl. (2008) har videreutviklet disse ideene og utdypet begrepene med også å fokusere på hvilke utfordringer matematikklærere står overfor i sin undervisning. Fauskanger og Mosvold (2015) peker på at den politiske interessen for å måle lærernes kunnskaper er økende, og det er grunn til å tro at dette også vil gjelde barnehagelærere. Utfordringen er ifølge Fauskanger (2015) at vi enda ikke helt vet hva som trengs av kunnskap for å være en god lærer eller hvilken måte som er best for å måle den kunnskapen som læreren bruker. Det samme vil nok gjelde for barnehagelærere.

I barnehagen ser det ut til at barnehagelærerne må klare å håndtere spenningen mellom aktiviteter som tar utgangspunkt i barnets perspektiv og fagområdets utgangspunkter, og at dette er sentralt i arbeidet med matematikk (Björklund \& Barendregt, 2016). Det er lite forskning som bruker begrepet matematikkdidaktikk i barnehagen, og dette ser ut til å være et noe kontroversielt begrep å bruke (Pramling Samuelsson, 2016). Likevel ser det ut til at i takt med den økende politiske interessen for å starte matematikkopplæringen allerede i barnehagen kommer forskning som tar til orde for å utvikle en realfagsdidaktikk i barnehagen (Brostrøm \& Frøkjær, 2016).

Tidligere forskning har i liten grad konsentrert seg om barnehagelærernes kompetanse til å skape felles oppmerksomhet mot matematikk i aktiviteter i barnehagens hverdag. Allerede sent på 1950-tallet introduserte Jerome Bruner begrepet joint attention (felles oppmerksomhet) - først med bakgrunn i analyser av nyfødtes blikk-kontakt med voksne (Bruner, 1995). En snever forståelse av joint attention vil være om en person ser i samme retningen som en annen person (Sigman \& Kasari, 1995), mens en bredere forståelse av begrepet også vil omfatte både verbale og non-verbale tilbakemeldinger og ansiktsuttrykk. Baldwin (1995) definerer joint attention som et felles og gjensidig mentalt bevissthetsnivå som to eller flere mennesker deler når de studerer den samme tingen. Det sentrale her er det mentale fokuset, og ikke bare at to mennesker ser i samme retning. Sigman og Kasari (1995) sier at «joint attention must involve an integration of information processing and emotional responsiveness» (s. 190). Dette handler ifølge Bruner om at en «ekspert» hjelper noen som ikke har den samme kompetansen (Wood, Bruner \& Ross, 1976). I sine tidligere arbeider argumenterer Bruner med at felles oppmerksomhet er viktig for barns læring og språkutvikling. Senere beskriver han den voksnes rolle i prosessen med å skape felles oppmerksomhet gjennom stillasbegrepet (Bruner, 1995). Forståelsen jeg legger til grunn, er at felles oppmerksomhet inkluderer respons fra den voksne til barnet, felles bevissthet og mental oppmerksomhet mot en aktivitet. En slik 
felles oppmerksomhet har vist seg viktig i barns språkutvikling (Tomasello \& Farrar, 1986), og det vil sannsynligvis også ha innvirkning på utviklingen av barns matematiske kompetanse og lærelyst for faget matematikk. Til sammenligning løfter Siraj-Blatchford (2009) sustained shared thinking fram som et aspekt som har innvirkning på pedagogikken i barnehager med høy kvalitet i interaksjonene mellom voksne og barn. Hun argumenterer for at det er visse kjennetegn mellom Bruners begreper joint attention og scaffolding med sustained shared thinking som hun sier er svært viktig som støtte for barns læring gjennom lek.

Fra høsten 2017 ble ny Rammeplan for barnehagens innhold og oppgaver (Kunnskapsdepartementet, 2017) gjort gjeldende. Som tidligere rammeplaner har denne planen prosessmål som sier at mot at barnehagelærerne gjennom aktiviteter i barnehagens hverdag skal støtte barns matematiske utvikling. Barnehagelærerne og de andre voksne i barnehagen skal oppmuntre barna til matematisk refleksjon og tankesett, de skal synliggjøre matematiske sammenhenger, de skal støtte opp omkring barnas læringsprosesser og sørge for at barna har tilgang til materiell. Videre skal barnehagelærerne bruke matematiske begreper reflektert og aktivt i hverdagen slik at barna utvikler forståelse for grunnleggende matematiske begreper, de skal inspirere barna til matematisk tenkning, og berike barnas lek og hverdag slik at barna kan få oppleve matematikkglede. Dette stiller noen konkrete krav til hvordan barnehagelærerne skal bruke sin kompetanse i matematikk, selv om planen ikke beskriver hvilken matematiske kompetanse barna forventes å få i barnehagen. Kravene til barnehagelærernes kompetanse er sammensatte. Som et minimum ser det ut til at de bør vise at de har en viss formell matematisk faktakunnskap og ferdighet, kjennskap til barns matematiske utvikling, matematikkdidaktisk kompetanse, samt sosial kompetanse for å ta ansvaret gitt i rammeplanen om at barna skal «oppleve et stimulerende miljø som støtter opp om deres lyst til å leke, utforske, lære og mestre» (Kunnskapsdepartementet, 2017, s. 18). Det å ha matematisk kompetanse er mer komplekst enn det styringsdokumentene i den skandinaviske barnehagetradisjonen kan gi inntrykk av (Björklund, 2013).

Barnehagelærernes kompetanse som gjennom formelle kunnskaper gir trygghet med begreper og kjennskap til prinsipper barnehagebarn trenger å møte, ser ikke ut til å være nok - kompetanse i didaktikk er avgjørende. Slik kan barnehagelærerne legge til rette for matematikkaktiviteter som er meningsfulle for både barna og dem selv, og samtidig ta utgangspunkt i barnas egne initiativ og interesser. Tidligere forskning ser ut til å konsentrere seg mest mot den fagdidaktiske delen (PCK) av barnehagelærernes kunnskap, og på denne måten forsøke å dokumentere hvilke kunnskaper de trenger for å gjøre matematikkundervisningen i barnehagen effektiv og mer systematisk. McCray og Chen (2012) sier det er tre typer kunnskap som er nødvendige for effektiv undervisning i barnehagen: Subject Matter Understanding, Teaching Techniques og Knowledge of Students' Development. PCK inneholder viktige aspekter av den 
matematiske fagkompetansen og omvendt. Dette er komplisert relatert til hverandre (Lee, 2010), og McCray og Chen (2012) konkluderer med at en god fagkunnskap i matematikk ofte oversees eller ignoreres i barnehagen. Forskningen ser ikke ut til å fokusere på barnehagelærernes kompetanse i å skape felles oppmerksomhet, verken hos barna eller hos seg selv. Likevel pekes det ut noen kompetanser som barnehagelærerne har - eller trenger å ha - som det etterlyses mer forskning for å dokumentere hvilke måter dette kommer til uttrykk på.

\section{Metode}

For å kunne besvare spørsmålet som stilles i studien har jeg studert et utvalg barnehagelærere i utøvelsen av hverdagsaktiviteter i barnehagen, og i etterkant intervjuet dem om deres arbeid med matematikk gjennom disse observerte aktivitetene. Jeg ønsket å rekruttere et utvalg barnehagelærere med ulik erfaring, fra ulike typer barnehager og både med og uten matematikk fra egen barnehagelærerutdanning, fordi jeg så for meg at det kunne være forskjeller på matematikkarbeidet alt etter hvilken formell kompetanse barnehagelærerne har, hvor mye erfaring de har og hvilken pedagogisk profil barnehagen har valgt å ha. På denne måten kan studien, gjennom å observere og analysere et utvalg barnehagelæreres praksis, bidra til å utvikle kunnskap om hvordan de arbeider med faget matematikk i barnehagen og hvilken kompetanse de bruker i dette arbeidet. Ut fra disse kriteriene ble fem ulike barnehager rekruttert til studien, og én barnehagelærer fra hver barnehage ble videoobservert og intervjuet. Tre av barnehagelærerne har 10 studiepoeng matematikk fra egen barnehagelærerutdanning, men ingen har studert matematikk ut over dette. De to mannlige barnehagelærerne er begge utdannet før matematikk ble eget fag i barnehagelærerutdanningen.

Jeg har gjort videoobservasjoner på mellom 22 og 60 minutter av hverdagsaktiviteter i de fem barnehagene, der barnehagelærerne leder grupper med barn på egen avdeling i barnehagen. Barnehagelærerne valgte hvilken type aktivitet de ønsket å gjøre, men jeg ba om at det skulle være noe de vanligvis gjør når de arbeider med matematikk i barnehagen - derfor defineres det som en hverdagsaktivitet. Analysen av aktivitetene ble brukt som grunnlag for utarbeidelse av en intervjuguide, og jeg ønsket at barnehagelærerne skulle kommentere uten andre føringer enn videoopptaket av dem selv i interaksjon med barnegruppene. For at de skulle kunne forberede seg, fikk barnehagelærerne opptaket av seg selv i aktiviteten på DVD i forkant av de semi-strukturerte intervjuene (Kvale, 2004) som foregikk noen uker senere. Under intervjuet så den enkelte barnehagelærer og intervjueren utvalgte deler av opptaket sammen, og barnehagelæreren kommenterte og ga sin mening til det som skjer. Disse refleksjonene tenkte jeg kunne gi en utvidet forståelse av matematikkarbeidets hvordan og hvorfor. En 
lignende bruk av video under intervju har også blitt gjort tidligere (f.eks. Jacobs \& Morita, 2002).

Tabell 1. Oversikt over deltakerne i studien. Barnas alder er skrevet som 4,11 år (4 år og 11 måneder)

\begin{tabular}{|c|c|c|c|c|}
\hline Barnehagelærer & Erfaring & $\begin{array}{l}\text { Valgt } \\
\text { aktivitet }\end{array}$ & $\begin{array}{l}\text { Deltakende } \\
\text { barn }\end{array}$ & Barnehage \\
\hline Harald & 17 år & $\begin{array}{l}\text { Bygge med } \\
\text { Lego-klosser }\end{array}$ & $\begin{array}{l}\mathrm{N}=6 \\
3,11-5,4 \text { år }\end{array}$ & $\begin{array}{l}\text { Barnehage uten særlig } \\
\text { profil }\end{array}$ \\
\hline Gunnar & 20 år & Mating av dyr & $\begin{array}{l}\mathrm{N}=4 \\
5,10-6,5 \text { år }\end{array}$ & Gårds- og naturbarnehage \\
\hline Siri & $\begin{array}{l}3 \text { år, men som } \\
\text { assistent tidligere }\end{array}$ & Kims lek & $\begin{array}{l}\mathrm{N}=7 \\
5,8-6,2 \text { år }\end{array}$ & $\begin{array}{l}\text { Barnehage uten særlig } \\
\text { profil }\end{array}$ \\
\hline Kamilla & $1,5 \mathrm{ar}$ & Baking & $\begin{array}{l}\mathrm{N}=4 \\
5,0-5,4 \text { år }\end{array}$ & $\begin{array}{l}\text { Barnehage uten særlig } \\
\text { profil }\end{array}$ \\
\hline Lillian & $15 \mathrm{a} r$ & Fysikkforsøk & $\begin{array}{l}\mathrm{N}=5 \\
4,9-5,2 \text { år }\end{array}$ & $\begin{array}{l}\text { Barnehage med satsnings- } \\
\text { område matematikk }\end{array}$ \\
\hline
\end{tabular}

Alle transkripsjoner er gjort av meg, og arbeidet med å se felles kjennetegn mellom det som skjer i opptaket og det barnehagelærerne sier i intervjuet, startet allerede under transkriberingen (Alvesson \& Sköldberg, 2008). Når videoopptak og intervju skulle analyseres, antok jeg at min egen erfaringsbakgrunn som barnehagelærer ville ha betydning for hva jeg analyserer meg fram til (Alvesson \& Sköldberg, 2008; Creswell, 2007; Stake, 1995). Jeg har derfor - selv om jeg selvsagt har forforståelser - forsøkt å legge fra meg oppfatninger om hva jeg selv mener er viktig basert på erfaringer fra lignende situasjoner i egen praksis. I analysen er oppmerksomheten rettet mot det som skjer i hverdagsaktiviteten og det barnehagelærerne sier i intervjuet, ikke hvilken kunnskap barnehagelærerne trenger i sitt profesjonelle arbeid med matematikk i barnehagen. Barnehagelærernes praksis er i hovedfokus, noe som kan nærme seg et svar på spørsmålet om hvilken kompetanse barnehagelærerne bruker og hvordan de selv ser på egen kompetanse. Dybdeanalyser av barnehagelærernes egne utsagn om temaet jeg fokuserer på, kan beskrives som ideen bak kvalitativ forskning (Creswell, 2007). Jeg har valgt å gjøre dette i barnehagelærerens naturlige setting - praksis i barnehagen - for best mulig å svare på spørsmålene jeg stiller.

Det transkriberte datamaterialet fra aktivitetene og intervjuene er analysert med konstant komparativ analysemetode (Postholm, 2010) for å identifisere hvordan barnehagelærernes kompetanse i matematikk brukes til å støtte barnas læring av matematikk. I første fase ble data fra aktivitetene analysert, og denne første åpne kodingen resulterte i 10 begynnende kategorier som jeg brukte som utgangspunkt til temaer for intervjuene med barnehagelærerne. Eksempler på temaer fra videobservasjonene er barns spontane innspill, hverdagsaktiviteter, hvorfor aktivitetene blir definert som matematiske, hvilke utfordringer barnehagelærerne står overfor, hvordan de holder barnas oppmerksomhet over lengre tid, bruken av matematiske spørsmål, om arbeidet kalles matematikkundervisning, og hvilken kompetanse de sier de bruker i arbeidet og hvor denne «kommer fra». På denne måten dannet den første kodingen grunnlaget for neste 
fase, der intervjuene ble analysert på samme måte for å kategorisere barnehagelærernes utsagn og svar. Barnehagelærerne beskriver hvordan de hadde tenkt på forhånd, hvilket materiell de hadde vurdert, de beskriver egen kompetanse, hvilken rolle de har i å støtte barnas læring, hvordan de knytter det de mener barna skal lære til målformuleringene i Rammeplanen, og hvordan de selv evaluerer arbeidet med faget matematikk i barnehagen.

Etter andre fase av analysene valgte jeg at de begynnende kategoriene fra fase én - samt barnehagelærernes egne refleksjoner og svar fra intervjuene - kan oppsummeres med hovedkategorien matematikkfokusert kompetanse. Arbeidet med matematikk i barnehagen stiller barnehagelærerne overfor noen utfordringer, og denne studiens bidrag kan være å peke på hva som er involvert i barnehagelærernes arbeid med matematikk. Det ser ut til at de bruker sin fagkompetanse i matematikk, didaktisk kompetanse i matematikk og kompetanse til å skape felles oppmerksomhet mot matematikk i sin profesjonelle praksis. Dette mener jeg med bakgrunn i analysene er dekkende beskrivelser av hvilke kompetanser disse barnehagelærerne bruker til å støtte barnehagebarnas læring av matematikk. De tre kategoriene overlapper hverandre, og danner til sammen barnehagelærernes matematikkfokuserte kompetanse. I den videre presentasjonen av studiens resultater har jeg valgt noen illustrerende eksempler fra transkripsjonene som viser fagkompetanse og didaktisk kompetanse de fem bruker, samt hvordan de arbeider med å skape felles oppmerksomhet.

Alle personer involvert i studien har fått fiktive navn, og barnas foreldre har gitt informert samtykke til videofilmingen av hverdagsaktivitetene. Barnas alder er skrevet som 4,11 år (4 år og 11 måneder). Studien er godkjent av NSD (Norsk senter for forskningsdata).

\section{Resultater}

Da vi så opptakene sammen, kommenterte barnehagelærerne fritt det som skjedde. Disse kommentarene er skrevet inn i transkripsjonene som innstikk i kursiv. Alle de fem barnehagelærerne sa at de trenger fagkompetanse i matematikk og at de har opparbeidet denne kompetansen både gjennom matematikkundervisningen de selv har fått som studenter og gjennom erfaring. De sa også at de bruker sin didaktiske kompetanse i planleggingen og gjennomføringen av hverdagsaktiviteter som inneholder arbeid med matematikk, og at de knytter dette opp mot mål i Rammeplanen. Barnehagelærerne hevder videre at de ikke klarer seg med fagkompetanse og didaktisk kompetanse; de må i tillegg ha kompetanse i å skape felles oppmerksomhet mot aktiviteten og det matematiske - og dette trenger i første omgang ikke å handle om faget matematikk. De mener dette kan være et utelukkende pedagogisk grep. Analysene av hverdagsaktivitetene og intervjuene med disse fem barnehagelærerne viser en kombinasjon som tidligere forskning ikke fokuserer på i beskrivelser av barnehagelæreres 
arbeid med matematikk i barnehagen. Tabell 2 oppsummerer studiens fremstilling av en matematikkfokusert praksis i norsk barnehage.

Tabell 2. Matematikkfokusert kompetanse i barnehagen

Matematikkfokusert kompetanse i barnehagelærernes profesjonelle praksis

Fagkompetanse i

matematikk
Didaktisk kompetanse i matematikk
Kompetanse til å skape felles oppmerksomhet mot matematikk hos barnehagelærer og barn

\section{Fagkompetanse i matematikk}

Barnehagelærerne i studien valgte geometri, tall, telling, sammenligning, måling og fysikk som matematikkaktiviteter. Gjennom å bruke matematiske begreper og stille spørsmål som oppfordrer barna til å reflektere matematisk, viser barnehagelærerne at de bruker egen matematisk kompetanse. Siri gjør sammenligninger mellom høy-lav, lang-kort, stor-liten og eldst-yngst gjennom Kims lek. Hun sier det matematiske språket må gjøres til en naturlig del av hverdagen, og sier hun stiller kontrollspørsmål til barna for å sjekke om de kan begrepenes betydning. Harald bruker matematiske begreper, og barna viser at de forstår selv om han i dette tilfellet ikke selv bruker korrekt matematisk begrep, men henviser til den todimensjonale formen på grunnflaten. Måten han stiller spørsmålene på gjør at barna engasjerer seg og samarbeider:

Harald (barnehagelærer): (holder opp en blå Lego-kloss (et rett prisme med rektangulær grunnflate)) Om du (...) Erik, hadde klart å finne to sånne blå rektangel til meg? Jeg skal bygge et tårn.

Haralds kommentar i intervjuet: «Her tenkte jeg å vinkle det litt mer inn på antall, så ble de jo veldig engasjerte»

Erik (4,4 år): Oi! To sånne?

Harald: To sånne rektangel. (Erik finner, Nora finner og Kaja finner)

Kaja (5,4 år): Jeg fant!

Lisa (4,9 år): Jeg fant!

Harald: Oi, da har jeg mange! (bygger dem sammen til et tårn) Da har jeg ganske mange, hvor mange har jeg nå mon tro? (Erik, Lisa og Kaja fortsetter å finne klosser)

Sammenhengen mellom det som skjer i aktiviteten og Harald sine kommentarer kan også vise at han er bevisst på at han skal bruke presise matematiske begreper når han beskriver det han ser og hva barna bygger av klossene. I denne videoobservasjonen er det flere tilfeller hvor barna anslår mengder uten å telle, kjent som subitizing (Sarama \& Clements, 2009). Harald holder samtalen gående med nye spørsmål, og viser at han vet at barn kan anslå mengder uten å måtte bruke ulike strategier for å telle:

Odin (4,11 år): Ja (begynner å telle klossene høyt mens han peker). En-to-tre-fire-fem(liten pause) seks. Seks...du fikk en ekstra. 
Haralds kommentar i intervjuet: «Dette var bra, du fikk en ekstra sier han. Det var den sjette som var ekstra. Han telte jo ikke, han trakk bare ifra en da. For det er jo det med telling, at du klarer å visualisere ting uten å fysisk telle de, uten å måtte peke.»

Harald: Veldig bra (setter ned klossene). Men da kan jeg jo...dette blir jo ei søyle faktisk, ser dere det?

Det er situasjoner der barna styrer dialogen og Kaja (5,4 år) begynner å stille spørsmål til de andre barna, mens barnehagelæreren inntar en mer passiv rolle. Likevel bidrar han med å identifisere det matematiske området måling, og på denne måten hjelpe barna med å sette ord på den matematikken de jobber med:

Kaja: (holder opp to gule bruer) Hvem er størst av disse her da?

Lisa: Peker på den ene

Kaja: (holder først opp den ene, så den andre) Er denne størst, eller er denne størst?

Lisa: (peker på den samme igjen) Denne, tror jeg

Harald: Interessant, hva er størst?

Kaja: (holder bruene helt inntil hverandre) Se! Den her er størst! (holder opp den ene).

Fordi at når vi skal måle (holder dem helt inntil hverandre igjen), så...er den størst (holder opp den samme Lego-klossen igjen).

Harald: Du måler den ja...

Harald identifiserer at barna måler, men kunne videre utnyttet denne situasjonen til å få barna til å reflektere rundt de matematiske begrepene størst, lengst, bredest, høyest og så videre - for å støtte barnas læring av matematikk, og vise barna at han selv kan bruke presise begreper.

Barnehagelæreren Lillian forteller at hun også bruker sin fagkompetanse til å hjelpe barnas foreldre til å bruke gode matematiske begreper når barna ikke er $\mathrm{i}$ barnehagen, og at dette er helt bevisst:

Intervjuer: Men er det...tenker du at det er en slags opplæring av foreldrene og?

Lillian: Ja, fordi at...si for eksempel at jeg har noen små som kommer til meg og kaller en form for en runding. Så er det ikke sånn at jeg sier at «det heter ikke runding», men jeg gjentar gjerne at «ja, den sirkelen». Og når jeg da har foreldresamtale, så kan jeg jo si «ja, barnet ditt har jo lært begrepene for trekant, kvadrat ...men sirkel, det bruker han ikke. Mulig at dere bruker det hjemme?»

I intervjuene forteller både Harald og Gunnar at de har et sterkt ønske om å utvikle sin egen matematiske kompetanse, og de forsøker å sette ord på hvor egen kompetanse «kommer fra» siden de ikke selv hadde matematikk i egen utdanning. Praksisen - sammen med egen lesing og kurs - mener de er viktig; det er ikke nødvendigvis slik at kompetansen kan knyttes direkte til undervisningen i barnehagelærerutdanningen. Egen kompetanse anser de som først og fremst praksisbasert selv om de hadde matematikk i videregående skole. 


\section{Didaktisk kompetanse i matematikk}

I tillegg til fagkompetanse i matematikk, viser barnehagelærerne i studien ulike muligheter og begrensninger $\mathrm{i}$ å lage en didaktisk plan over denne typen aktiviteter når temaet skal være matematikk. De lager alle en grovskisse over hva de skal jobbe med og hva de tenker at barna skal lære av matematikk i disse hverdagsaktivitetene.

Når spontane utsagn fra barna dukker opp, beskriver de måten å takle dette på som personavhengig og knyttet til erfaring. Siden fokus skulle være mot matematikk, var det lettere å jobbe videre mot matematikk også i spontane innspill. I forkant av videoobservasjonene hadde barnehagelærerne en oppfatning om at det ville være utfordrende å engasjere seg og være i aktiviteten kun konsentrert mot matematikk, uten å jobbe med andre fagområder. I etterkant beskriver de det som enkelt. Både aktiviteter og materiell ser de på som virkemidler for at barna skal lære noe. Barnehagelærerne viser på denne måten et bevisst forhold til de sosiokulturelle redskapene og bruken av de materielle så vel som de språklige verktøyene (Säljö, 2001). Refleksjon om barnas nivå og hvordan barnehagelæreren kan tilrettelegge for at alle barna kan få strekke seg litt, ser ut til å være viktig i planleggingen:

Intervjuer: Du sier det litt etter det du vet om kompetansen til hvert enkelt barn?

Gunnar: Ja, for hvis jeg på en måte kan få det barnet til å strekke seg litt, litt og få det til, så ønsker jeg jo helst det, sant? Men hvis jeg på en måte gir, hvis utfordringen blir for stor og jeg vet at den blir for stor, så begrenser jeg det heller hvor mye jeg gjør det. Litt for at det ikke bare, det skal være kjekt, det skal være liksom en positiv opplevelse, ikke bare noe sånn «det kunne ikke jeg». «Jeg fikk ikke til noen ting jeg». Det er jo ikke noe kjekt å gå fra gruppa der sånn, mye kjekkere å komme med arket og «se hva jeg fikk til» (viser med hånda hvordan han vifter med arket). Sant, altså. Mestringsfølelsen er viktigst.

Målene for hva barna skal lære om matematikk knytter de alle opp mot Rammeplanen (Kunnskapsdepartementet, 2017), men sier at det skjer i samspill med innholdet, barnehagelærerens intensjoner og barnas erfaringer. For at det skal være gjenkjennbart når barna skal lære seg nye matematiske begreper, bruker Lillian kjent materiell for å illustrere og gjøre det lettere for barna:

Intervjuer: Hvor mye av den matematiske delen hadde du planlagt på forhånd?

Lillian: Ganske mye, men noe kommer jo litt sånn undervegs og, litt sånn spontant. Men altså, som for eksempel i forhold til den ballongen som skulle blåses opp, da hadde jeg jo lagd bilder og det var jo gjennomtenkt for det at jeg tenkte at det var bilde av en ballong. For å vise at da trenger de en av hver, altså de trenger ei flaske, en ballong og det var vel der også de skulle måle opp vann hvor jeg hadde med det målebegeret. Hvor de skulle ha tretti milliliter, milliliter det var et nytt begrep for de. Og så tenkte jeg, for å illustrere hvor mye de faktisk trenger, så skrev jeg 10-20-30 på Duplo-klossene for jeg tenkte at da er det lettere for dem å skjønne at det er en sammenheng mellom det målebegeret og hvor mange ganger de skal fylle oppi det målebegeret med å bruke...så såg jeg jo at noen tok den ganske lett. Det var en grei 
måte å gjøre det på. For dette med milliliter det var jo egentlig ganske nytt for de, de er ikke så veldig gode å ta de med på kjøkkenet og holde på med måling, nei.

Gunnar forteller i intervjuet om egen kompetanse og hva som behøves for å lære barna matematikk, og sier at selv om han var flink i matematikk selv så blir han ikke automatisk en god lærer. Han sier at han trenger kompetanse i å vite hva barn trenger og hva barn kan lære seg, han trenger kompetanse i å tilrettelegge for matematikk i hverdagsaktivitetene, og han trenger å tilrettelegge det barna skal lære til hver enkelt barnegruppe.

\section{Kompetanse til å skape felles oppmerksomhet}

I tillegg til fagkompetanse og didaktisk kompetanse indikerer resultatene av analysene at kompetanse i å skape felles oppmerksomhet hos barnehagelæreren og barna er sentralt for arbeidet med matematikk i barnehagen. Harald sier i intervjuet at engasjement fra hele personalet har stor betydning for arbeidet med matematikk i barnehagen. Han sier at engasjement og nysgjerrighet for sammenhenger og sammenligninger hos de voksne «smitter over» til barna. Mens vi ser filmen blir han oppmerksom på at barna er engasjerte av matematikk. Dette mener han kommer av at han selv klarer å være engasjert; mye av svarene hans på barnas spontane innspill og spørsmål som dukker opp, er ikke planlagt eller mulig å planlegge. Likevel sier han at han klarer å knytte det til matematikk. Når han ser opptaket, sier han at mange av aktivitetene de gjør sammen ser enkle og meningsløse ut - men han sier at han formidler kunnskap, og barna lærer seg å se matematiske sammenhenger i aktivitetene. Ett eksempel han trekker fram er når han lager en konkurranse mellom hjul av ulike former for å se hva som triller best, noe som i utgangspunktet ikke handler om matematikk. Han bemerker at han ser seg selv som engasjert $\mathrm{i}$ å finne ut av dette, og sier at ansiktsuttrykkene til barna forteller at også de er det.

Harald: Da skal vi se hva som triller best. Et kvadratisk hjul eller et vanlig hjul. Er dere klare?

Haralds kommentar i intervjuet: «Engasjementet er på topp. Det er jo egentlig så lite, det er egentlig så lett og meningsløst men det blir jo faktisk litt filosofisk.»

Kamilla opplever i aktiviteten at barna begynner å diskutere hvem som har fått hjulpet til mest og minst. Dette tar Kamilla utgangspunkt i, siden barna er opptatt av det, og trekker diskusjonen mot matematikk. Jeg spør henne i intervjuet om dette var noe hun kom på der og da eller hadde planlagt på forhånd:

Intervjuer: Men det at de begynner å lage en slags statistikk på hvor mange ting de har hjulpet til med hver, var det noe du hadde tenkt på forhånd?

Kamilla: Nei, ikke at kanskje de hadde sånn men jeg vet jo fra før av at de er veldig sånn, nå har jeg gjort så mange ting så eller ja, det...hvem som har flest ting og så altså den, det er slike ting som vi på en måte er opptatt i forskjellige situasjoner. Og det som, det som var planlagt var at jeg ville prøve å fordele sånn at det ble mest mulig 
jevnt fordelt i forhold til å hjelpe mellom de. Og det er noe som jeg er bevisst på liksom sånn generelt, å prøve å fordele rundt sånn at ikke det blir en eller to som får gjøre mye mer enn de andre.

Intervjuer: For du plukker jo opp den der og lager på en måte et regnestykke av det? Kamilla: Ja, og det var jo litt sånn som jeg tenker at da når jeg merket den at de var på det så er det liksom det å snappe opp sånne småting og bygge på det som jeg liksom...ja, jeg så det og her!

Gunnar, som har delt ut et skjema til barna for å føre opp hvor mye mat de forskjellige dyra på gården får, sier i likhet med de andre at planleggingen av denne hverdagsaktiviteten mot matematikk var lettere siden jeg hadde spurt om det på forhånd.

Intervjuer: Er det lettere sånn som når jeg kommer for å filme, å fokusere på matematikk da, eller klarer du det like bra i hverdagen?

Gunnar: Jeg klarer det nok ikke like bra i hverdagen. For nå, jeg merker jo med en gang, sånn som når de får et ark der...sant, så blir fokuset for barna...så blir fokuset mye sterkere. Så selv om på en måte vi gjør det samme muntlig, så blir ikke det visuelle det samme. Sant, her får de på en måte tenke, og se for seg, og så skrive ned streker eller tall, sant altså. For det å gjøre det på den måten der, var jo egentlig litt artig å se på forskjellen fordi at jeg merket at ungene blir mer engasjerte, de blir mer og så jobber vi jo mye med å gjøre ting, få til ting, mestring og sånne ting. Og når de får noe i hånda, en oppgave i hånda sant. Da er det litt sånn, okei, dette skal vi få til sant og du ser...bare de får det arket, klakk - der går de ett hakk opp med en gang. Litt mer stolte og nå «vi skal ha matteopplegg vi sant». Så...ja, det er gjerne en ting vi kunne vært litt flinkere til å gjort litt mer sånn. Men jeg syns likevel det er viktig å gjøre det litt i det daglige og, altså det på en måte å prate med ungene om ting. Bruke tall, og bruke ord og bokstaver og lyder. Altså alt som går på språk og matematikk. Bruke og gjenta og repetere og like mye tall som lyd egentlig sant altså. Vi er veldig flinke på lyder, men det er liksom det å «her var det to sauer» istedenfor «her er det sauer».

Alle fem barnehagelærerne forteller om egen bevissthet i forhold til faget matematikk, og at det var lettere å fokusere når man visste hva man skulle jobbe med enn i den daglige praksisen der hvilket som helst av fagområdene kan dukke opp når som helst. Barnehagelærerne har bevisste strategier for at barna skal lære matematikk i hverdagsaktivitetene, og de sier at det skjer gjennom dialog og samtale mellom dem selv og barna. Harald improviserer sammen med barna på bakgrunn av hva de holder på med. Han «tuller og tøyser» mye for å motivere og hjelpe barna å holde seg konsentrert mot faget matematikk - selv om hovedmålet noen ganger er å finne en aktivitet som er gøy for barna. Dette beskriver barnehagelærerne som læring i praksis og i naturlige omgivelser, der prosessen er det viktige og aktivitetene er lystbetont. Det er kun Gunnar av de fem barnehagelærerne som har sagt til barna at de skal jobbe med matematikk i aktiviteten; de andre har ikke brukt begrepet matematikk. Siri sier det er litt rart at hun ikke bruker begrepet matematikk overfor barna; hun hadde fortalt i forkant at de skulle leke Kims lek og jobbe med måling, men hun brukte ikke 
begrepet matematikk. De andre sier at barna ikke er klar over at de lærer matematikk i denne aktiviteten, men de som barnehagelærere vet at barna tilegner seg grunnleggende matematikk.

Harald stiller spørsmål om «hvor mye skal de lære?». Han beskriver sine tanker om barns progresjon i læring og stiller spørsmål om han i noen tilfeller bør spare litt av læringen til de kommer på skolegruppa neste år slik at de ikke kan for mye? Han har observert at femåringene dette året kan nesten like mye som seksåringene året før. Han stiller spørsmål om årsaken til dette: «Er barna mer oppegående eller handler det om at vi er her?» Han sier at begrepet undervisning ikke er beskrivende for arbeidet med matematikk i barnehagen. Slik han forstår det, vil det medføre mer gjennomgang og formidling av begreper fra den voksne til barna selv om det alltid vil være barnehagelærerens ansvar å tilpasse læring og hvilke utfordringer de skal gi barna på de ulike alderstrinn. Det er kun Gunnar som svarer at undervisning er det som best beskriver hans profesjonelle praksis. Han tror barna forstår at han er læreren og ett av fagene han underviser i er matematikk.

\section{Diskusjon}

I likhet med begrepet undervisning er begrepet didaktikk heller ikke vanlig å bruke i barnehagen (Pramling Samuelsson, 2016), men barnehagelærerne i denne studien forteller at det matematiske innholdet planlegges med tanke på valg av aktiviteter og barnegruppas sammensetning og nivå - knyttet til målene i styringsdokumentene. Hvordan barnehagelærerne handler og ikke handler i forhold til målene og hvilke konsekvenser dette har, vil dermed ha innvirkning på barnas læringsutbytte i aktiviteten. Derfor planlegger disse barnehagelærerne barns læring ut fra et syn på undervisning som samspill mellom det faglige innholdet, barna og seg selv som lærer. Målene for hva barna skal lære om matematikk sier de finnes i Rammeplanen. De velger aktiviteter som de selv mener inneholder matematikk, og de sier i intervjuene at tilrettelegging for barnas læring av matematikk er beskrivende for det de gjør i disse aktivitetene men fire av fem vil ikke kalle arbeidet for matematikkundervisning.

Barnehagelærerne viser at de reflekterer omkring når barna trenger støtte og når de trenger utfordringer, og tar stilling til hvordan barna lærer. Tidligere forskning poengterer at barna må få skape sin egen forståelse, ikke kun få reprodusert kunnskap fragmentert overført av barnehagelæreren (Doverborg et al., 2013). Barna må få anledning til å oppdage mønstre og se sammenhenger fra en situasjon til en annen, og barnehagelæreren har dermed en viktig rolle med å hjelpe barna å rette oppmerksomhet mot alle matematikkens ulike områder. Harald kaller planleggingen for «tunet inn mot matematikken». Likevel sier de at planleggingen må være åpen nok til å kunne jobbe med barnas spontane innspill og bygge videre på disse, samt på bakgrunn av observasjoner og 
kunnskap om barn skape felles faglig oppmerksomhet. Dette er i samsvar med Säljö (2001) som sier at hverdagslige praksiser i seg selv inneholder pedagogikk og at kompetansen er situert i praksis. McCray og Chen (2012) konkluderer med at barnehagelærerne trenger å gjenkjenne viktigheten og kompleksiteten i barns erfaringer og knytte erfaringene sammen med nye. Selv om denne forskningen har en annen innfallsvinkel, ser det ut til at resultatene er sammenfallende.

I den nordiske barnehagetradisjonen er det kanskje slik at den sterke vektleggingen av barnas læring av matematikk gjennom lek og hverdagsaktiviteter utfordrer barnehagelærernes matematiske kompetanse. Rammeplanen skiller ikke mellom formelle og uformelle læringssituasjoner, siden begge skal ha en pedagogisk hensikt (Kunnskapsdepartementet, 2017). Det som ser ut til å være viktig for barnehagelærerne i disse voksenstyrte hverdagsaktivitetene, er at de retter egen oppmerksomhet mot faget matematikk og ikke «bare» lek; de bruker sin kompetanse til å gjøre aktivitetene matematiske. Siri sier at aktiviteten blir matematisk fordi hun bevisst tilfører matematiske begreper i dialogen. Arbeidsmåten krever konsentrasjon, bevissthet og god ledelse - de sier det var lettere å knytte an til faget siden de hadde tenkt på dette i planleggingen og at de visste jeg skulle se etter matematikk. Samtidig kommenterer de også at de selv bruker matematiske begreper upresist.

Mellom ulike barnehagetradisjoner vil det være likheter og forskjeller, men kompetansebeskrivelser fra formelle undervisningssituasjoner i «pre-primarytradisjonen» har likhetstrekk med de mer uformelle i den nordiske barnehagetradisjonen (jf. McCray \& Chen, 2012). Björklund og Barendregt (2016) konkluderer med at det i Sverige er utfordringer i matematikkarbeidet knyttet opp til både barnehagelærernes manglende målformuleringer og forståelsen av hvordan de skal presentere matematikken i barnehagen. Dette indikerer at det også i en sosialpedagogisk barnehagetradisjon er viktig at barnehagelærerne bruker både fagkompetanse og didaktisk kompetanse til å tilrettelegge for matematikkaktiviteter som barna kjenner igjen fra sitt dagligliv både i barnehagen og fra andre arenaer. I tillegg må barna oppleve konsentrerte barnehagelærere som kan motivere, undre seg og finne ut av matematikken sammen med barna; for å få til dette kreves det en kompetanse til å skape felles oppmerksomhet mot faget matematikk. Lee (2010) er opptatt av at undervisningen skjer på en forståelig måte for barna, og dette innebærer at barnehagelæreren kontinuerlig må vurdere barnas kompetanse og tilpasse hva barna skal lære til dette.

Hverdagsaktivitetene kunne vært knyttet til «bare» lek, og barnehagelærerne sier selv at dette noen ganger er hovedmålet. Det skjedde imidlertid noe «mer» siden de i aktivitetene var konsentrert på at det skulle være et matematisk innhold. Barnehagelærerens matematikkfokus og intensjoner vil dermed ha betydning for barnas læringsutbytte, noe også Siraj-Blatchford (2009) finner i voksenstyrte lek-aktiviteter. Barnehagelærerne bruker sin fagkompetanse og didaktiske kompetanse i arbeidet med å skape felles oppmerksomhet gjennom eksempelvis å formulere spørsmål og tilbakemeldinger (Sæbbe \& Mosvold, 2015) og være 
undrende sammen med barna og på denne måten styre samtalene og dialogen mot faget matematikk. I første omgang ser det ikke ut til at ønsket om å skape felles oppmerksomhet er knyttet opp til matematikk, men siden barnehagelærerne selv er konsentrerte mot matematikk, klarer de å knytte også barnas spontane innspill mot matematikken i aktivitetene ved eksempelvis å selv benytte matematiske begreper. Dette kan tyde på at det ville være bra for arbeidet med matematikk i barnehagen om barnehagelærerne setter av tid til utelukkende å jobbe med matematikk.

Matematikk som fag i barnehagelærerutdanningen ble innført etter at to av barnehagelærerne i denne studien var utdannet, men disse to mener de har opparbeidet seg kompetansen gjennom praksis, god kjennskap til læreplaner, veiledning og korte kurs. Begge sier at deres lange erfaring fra barnehage gjør dem bedre i stand til å gjøre de ulike aktivitetene i barnehagen matematiske ved å innføre matematiske begreper, formulere matematiske spørsmål eller legge til rette for matematisk refleksjon og logiske løsningsforslag. Ball (2017) sier at det som er viktig for god matematikkundervisning, ikke er så enkelt som å se hvor mange studiepoeng læreren har. Gunnar sier at «en kan godt gå på 50 kurs og lese 100 bøker, men du blir ikke noe flinkere for det». Matematikkundervisningen i barnehagelærerutdanningen er viktig, men den danner kun utgangspunktet (jf. Hundeland, 2010) før man ifølge barnehagelærerne utvikler egne erfaringer og strategier. Kommunikasjon, interaksjon, transformasjon, engasjement og bevissthet i måter å stille spørsmål om hvor mye barna skal lære - og når de skal lære det - ser ut til å være viktig for disse fem barnehagelærerne. Dette viser at barnehagelærerne i sitt fagdidaktiske arbeid bruker språket som et kulturelt redskap for å fremme barns læring (Säljö, 2001).

\section{Konklusjoner}

Den kompetansen barnehagelærere bruker når de skal støtte barns læring av matematikk i hverdagsaktiviteter, er matematikkfokusert. Barnehagelærerne må ha en viss fagkompetanse i matematikk og vite hvordan de skal gjøre denne tilgjengelig for barna. Dette støttes både av analyser av observasjoner og av barnehagelærernes egne refleksjoner om praksis, og det samsvarer med tidligere nevnte forskning av matematikklæreres kompetanse i skolen og barnehagelæreres matematiske kompetanse i andre barnehagekontekster. Studien viser barnehagelærernes syn på tilrettelegging for læring av matematikk som et samspill mellom barna, det faglige innholdet og egne intensjoner, men fire av fem bruker ikke begrepet matematikk eller matematikkundervisning om eget arbeid. I tillegg ser det ut til at disse norske barnehagelærerne bruker kompetanse til å skape felles oppmerksomhet, og dette ser ut til å kunne være spesifikt knyttet til arbeidet med matematikk i en norsk barnehagetradisjon. Særtrekkene ved den norske/nordiske barnehagetradisjonen (OECD, 2006, 2012) har sammenheng 
med den uformelle måten arbeidet med å støtte barns læring av matematikk ofte gjøres på. Den essensielle forskjellen mellom utsagnene «her var det to sauer» og «her var det sauer» kan være et eksempel på hvordan barnehagelærerne presenterer og bruker matematiske begreper for barnehagebarna i sin matematikkfokuserte profesjonelle praksis.

Denne studien viser at forskningen til Lee (2010), samt McCray og Chen (2012) - som fokuserer på hvilken kompetanse barnehagelærerne trenger - også gir nyttige innspill i diskusjonen om hvilken kompetanse de bruker, tross forskjeller i barnehagetradisjoner. Kombinasjonen av Shulmans (1986) kategorier og Bruners (1995) utvidede mening av felles oppmerksomhet beskriver barnehagelærernes matematikkfokuserte kompetanse i den sosialpedagogiske barnehagetradisjonen, og jeg argumenterer for at dette er en av forskjellene i kravet til barnehagelærernes kompetanse mellom barnehagetradisjonene. Barnehagelærerne sier det er viktig at de selv bruker presise matematiske begreper, noe studien viser at de ikke alltid gjør. At barnehagelærerne vet hvordan de skal støtte barns matematiske utvikling gjennom å være matematisk tilstedeværende i både formelle og uformelle aktiviteter, er viktig. For at barna skal møte kompetente pedagoger i barnehagen, og for å tilrettelegge for en god undervisning i matematikk i barnehagelærerutdanningen, bidrar denne studien med kunnskap om forholdet mellom barnehagelærernes kompetanse og hvordan de støtter barns læring av matematikk i barnehagen.

For å videreutvikle den forskningsbaserte kunnskapen om barnehagelæreres matematiske kompetanse, trenger vi mer forskning som går grundig inn i analyser av hverdagsaktiviteter i barnehagen for å forstå hva som er viktig i arbeidet med matematikk i barnehagen og hva dette arbeidet består av. Denne studien undersøker fem ulike barnehagelærere med og uten matematikk fra egen barnehagelærerutdanning, og det kan ikke med bakgrunn i en slik kvalitativ studie generaliseres at disse resultatene gjelder alle barnehagelærere. Derimot kan studien gi noen interessante indikasjoner som kan følges opp i andre studier hvor en undersøker hvilke strategier barnehagelærere bruker for å skape felles oppmerksomhet og hvilken betydning formell matematisk fagkompetanse kan sies å ha for arbeidet med matematikk i barnehagen.

\section{Om forfatteren}

Per-Einar Sæbbe er stipendiat i utdanningsvitenskap ved Institutt for barnehagelærerutdanning på Universitetet i Stavanger. Hans forskningsinteresser er barnehagelærernes undervisningskompetanse i matematikk, samt utvikling av innhold i begrepene undervisning og didaktikk i barnehagen.

Institusjonstilknytning: Universitetet i Stavanger, Institutt for barnehagelærerutdanning, Fakultet for utdanningsvitenskap og humaniora, 4036 Stavanger.

E-post: per-einar.saebbe@uis.no 


\section{Referanser}

Alvesson, M. \& Sköldberg, K. (2008). Tolkning och reflektion: Vetenskapsfilosofi och kvalitativ metod (2. opplag). Lund: Studentlitteratur.

Baldwin, D. A. (1995). Understanding the link between joint attention and language. I C. Moore \& P. J. Dunham (red.), Joint attention: Its origin and role in development (s. 131158). Hillsdale, NJ: Lawrence Erlbaum.

Ball, D. L. (2017). Uncovering the Special Mathematical Work of Teaching. I G. Kaiser (red.), Proceedings of the $13^{\text {th }}$ International Congress of Mathematical Education (s. 1134). Springer.

Ball, D. L. \& Forzani, F. (2009). The work of teaching and the challenge for teacher education. Journal of Teacher Education, 60(5), 497-511.

Ball, D. L., Thames, M. H. \& Phelps, G. (2008). Content knowledge for teaching: What makes it special? Journal of Teacher Education, 59(5), 389-407.

Björklund, C. (2013). Didaktisk diskussion om barnträdgårdslärares möjligheter att arbeta med matematik i findländsk småbarnsfostran. Nordisk Barnehageforskning, 6(7), 1-12.

Björklund, C. \& Barendregt, W. (2016). Teachers' Pedagogical Mathematical Awareness in Swedish Early Childhood Education. Scandinavian Journal of Educational Research, 60(3), 359-377.

Brostrøm, S. \& Frøkjær, T. (2016). Realfag i barnehagen - barn og barnehagelærere undersøker naturens lovmessigheter. Oslo: Pedagogisk forum.

Bruner, J. (1995). From joint attention to the meaning of the minds: An introduction. I C. Moore \& P. J. Dunham (red.), Joint attention: Its origin and role in development (s. 114). Hillsdale, NJ: Lawrence Erlbaum.

Carlsen, M., Erfjord, I. \& Hundeland, P. S. (2010). Orchestration of mathematical activities in the kindergarten: the role of questions. I V. Durrand-Guerrier, S. Soury-Lavergne \& F. Arzarello (red.), Proceedings of the Sixth Congress of the European Society for Research in Mathematics Education (s. 2567-2576). Lyon, France: Institut National de Recherche Pédagogique.

Creswell, J. W. (2007). Qualitative inquiry and research design: Choosing among five approaches (3. utgave, 2013). London, UK: SAGE.

Doverborg, E., Pramling, N. \& Pramling Samuelsson, I. (2013). Att undervisa barn i förskolan. Göteborg: Lieber.

Fauskanger, J. (2015). A måle og studere matematikklæreres undervisningskunnskap. En studie av hvordan det er mulig å måle og studere matematikklæreres undervisningskunnskap, og mulige begrensninger og styrker ved måter en måler og studerer kunnskap på. Doktoravhandling nr. 249, Universitetet i Stavanger.

Fauskanger, J. \& Mosvold, R. (2015). The difficulties of measuring types of mathematics teachers' knowledge. I H. Silfverberg, T. Kärki \& M. S. Hannula (red.), Nordic research in mathematics education - proceedings of NORMA14, Turku, June 3-6, 2014 (s. 71-80). Studies in Subject Didactics 10. Turku: The Finnish Research Association for Subject Didactics.

Ginsburg, H. P. \& Amit, M. (2008). What is teaching mathematics to young children? A theoretical perspective and case study. Journal of Applied Developmental Psychology, 29(4), 274-285.

Hoover, M., Mosvold, R., Ball, D. L. \& Lai, Y. (2016). Making progress on mathematical knowledge for teaching. The Mathematics Enthusiast, 13(1-2), 3-34.

Hundeland, P. S. (2010). Larerens motiver og valg. En studie om matematikklærere på videregående trinn. Kristiansand: Portal Forlag. 
Jacobs, J. K. \& Morita, E. (2002). Japanese and American teachers' evaluations of videotaped mathematics lessons. Journal for Research in Mathematics Education, 33(3), 154-175.

Kunnskapsdepartementet (2017). Rammeplan for barnehagens innhold og oppgaver. Oslo: Kunnskapsdepartementet.

Kunnskapsdepartementet (2015). Tett på realfag. Nasjonal strategi for realfag i barnehagen og grunnopplceringen (2015-2019). Oslo: Kunnskapsdepartementet.

Kunnskapsdepartementet (2013). Meld. St. 24 (2012-2013): Framtidens barnehage. Oslo: Kunnskapsdepartementet.

Kunnskapsdepartementet (2006). Rammeplan for barnehagens innhold og oppgaver. Oslo: Kunnskapsdepartementet.

Kvale, S. (2004). Det kvalitative forskningsintervju. (6. utgave) Oslo: Gyldendal akademisk forlag.

Lee, J. (2010). Exploring kindergarten teachers’ pedagogical content knowledge of mathematics. International Journal of Early Childhood, 42(1), 27-41.

McCray, J. S. \& Chen, J.-Q. (2012). Pedagogical content knowledge for preschool mathematics: Construct validity of a new teacher interview. Journal of Research in Childhood Education, 26(3), 291-307.

Mosvold, R. (2017). Studier av undervisningskunnskap i matematikk: Internasjonale trender og nordiske bidrag. Nordic Studies in Mathematics Education, 22(2), 51-69.

Mosvold, R., Bjuland, R., Fauskanger, J. \& Jakobsen, A. (2011). Similar but different investigating the use of MKT in a Norwegian kindergarten setting. I M. Pytlak, T. Rowland \& E. Swoboda (red.), Proceedings of the Seventh Congress of the European Society for Research in Mathematics Education (s. 1802-1811). University of Rzeszów, Poland.

OECD (2006). Starting Strong II: Early childhood education and care. Paris: Organisation for Economic Co-operation and Development.

OECD (2012). Starting Strong III: A Quality Toolbox for Early Childhood Education and Care. OECD Publishing.

Postholm, M. B. (2010). Kvalitativ metode: En innføring med fokus på fenomenologi, etnografi og kasusstudier. Oslo: Universitetsforlaget.

Pramling Samuelsson, I. (2016). Varför är begreppen didaktik och undervisning så kontroversiella i förskolans praktik? I A. Skriver Jensen \& O. H. Hansen (red.), Pcedagogen, professoren, personligheden. Festskrift til Stig Broström (s. 81-89). København: Dafolo.

Reikerås, E., Løge, I. K. \& Knivsberg, A. M. (2012). The mathematical competencies of toddlers expressed in their play and daily life activities in Norwegian kindergartens. International Journal of Early Childhood, 44(1), 91-114.

Sarama, J. \& Clements, D. (2009). Early childhood mathematics education research. Learning trajectories for young children. New York: Routledge.

Shulman, L. (1986). Those who understand: Knowledge growth in teaching. Educational Researcher, 15(2), 4-14.

Sigman, M. \& Kasari, F. (1995). Joint Attention Across Contexts in Normal and Autistic Children. I C. Moore \& P. J. Dunham (red.), Joint attention: Its origin and role in development (s. 189-203). Hillsdale, NJ: Lawrence Erlbaum.

Siraj-Blatchford, I. (2009). Conceptualising progression in the pedagogy of Play and Sustained Shared Thinking in early childhood education: A Vygotskian perspective. Educational \& Child Psychology, 26(2), 77-89.

Stake, R. E. (1995). The art of case study research. London, UK: SAGE publications.

Sæbbe, P.-E. \& Mosvold, R. (2015). Asking productive mathematical questions in kindergarten. I K. Krainer \& N. Vondrova (red.), Proceedings of the Ninth Congress of 
the European Society for Research in Mathematics Education (s. 1982-1988). European Society for Research in Mathematics Education.

Säljö, R. (2001). Lcring i praksis: et sosiokulturelt perspektiv. Oslo: Cappelen akademisk. Tomasello, M. \& Farrar, M. J. (1986). Joint attention and early language. Child Development, 57(6), 1454-1463.

Wood, D. J., Bruner, J. S. \& Ross, G. (1976). The role of tutoring in problem solving. Journal of Child Psychology and Psychiatry, 17(2), 89-100. 